\title{
Problems of water buffalo breeding in Turkey and suggestions for its development
}

\author{
Bahri Karli ${ }^{1}$, Mevlüt Gül ${ }^{1 *}$, Metin Göksel Akpinar ${ }^{2}$, Yavuz Tascioğlu², Yalçın Bozkurt ${ }^{3}$ \\ ${ }^{1}$ Süleyman Demirel University, Faculty of Agriculture, Department of Agricultural Economics, Isparta, Turkey. \\ ${ }^{2}$ Akdeniz University, Faculty of Agriculture, Department of Agricultural Economics, Antalya, Turkey. \\ ${ }^{3}$ Süleyman Demirel University, Faculty of Agriculture, Department of Animal Science, Isparta, Turkey.
}

\begin{abstract}
The objective of the study was to present the current situation of water buffalo breeding in Turkey, determine the relevant problems, and propose suggestions for its improvement. The research data were collected at the "Focus Group Interviews" with the sector actors from the cities engaged in buffalo breeding between July and September of 2015. The cities included Afyonkarahisar, Bitlis, Diyarbakir, Istanbul, Muş, Samsun, and Tokat, where buffalo breeding was usually practiced by small-scale family enterprises that used traditional husbandry methods. The variables chosen as indicators of yield included milk yield, meat yield, and lactation period, which were found to be below global averages. The study revealed lack of adequate record-keeping of enterprises raising water buffalo. Buffalo breeders should take necessary steps to improve their strategies to increase buffalo milk yield, while government agencies should protect wetlands and prevent their unintended use, making relevant legal arrangements where necessary. Buffalo meat and milk should be promoted with an emphasis on their superior nutritional values. For the development of buffalo breeding in Turkey, necessary steps should be taken on both national and local levels.
\end{abstract}

Key Words: water buffalo, production, productivity, SWOT analysis

\section{Introduction}

Although Turkey is a suitable country for animal husbandry due to its soil and climate characteristics, the present potential is not adequately exploited and the targeted success in animal production cannot be achieved. Animal production deficit is compensated through imports. These imports might include import of livestock or red meat, or sometimes both. The main reason for this is the lack of modern enterprises engaged in livestock production and the yield per unit animal is lower than in developed countries. Moreover, high marketing margins arising from the inadequacy of the marketing organization and its infrastructure at the level of such enterprises constitute a significant constraint in the development of animal production activities.

The value of agricultural production in Turkey was 248,925,000 TL (Turkish lira) in 2015 and the share of

Received: September 14, 2017

Accepted: October 22, 2017

*Corresponding author: mevlutgul@sdu.edu.tr

Copyright (C) 2018 Sociedade Brasileira de Zootecnia. This is an Open Access article distributed under the terms of the Creative Commons Attribution License (http://creativecommons.org/licenses/by/4.0/), which permits unrestricted use, distribution, and reproduction in any medium, provided the original work is properly cited. animal production in agricultural production value was $51.73 \%$ (TUIK, 2017). The increase in the quantity and diversity of the support given to the animal husbandry in recent years has been accompanied by increases in both the number of animals and the amount of production. In fact, there was a $30.39 \%$ increase in the number of bovine animals, $295.39 \%$ increase in the red meat production obtained from bovine animals, and $191.48 \%$ in the milk production obtained from bovine animals between 2000 and 2016. The effects of support given to the livestock sector are seen both in the number of cattle, in red meat and milk production, and the increase is in a positive trend.

However, the rise in the number of bovine animals and animal production was not reflected in the number of water buffalo and buffalo products. The number of water buffalo was 146,000 in 2000 , but this figure declined to 142,073 head in $2016(2.69 \%)$, while the buffalo milk production decreased from 67,330 to 63,085 tons $(6.31 \%)$ in the same period and buffalo meat production fell by $91.33 \%$, from 4,047 to 351 tons (TUIK, 2017). Despite the state subsidies given to buffalo farming, there has been a decrease in buffalo population and production, which could be attributed to the fact that buffalo breeding largely rests on wetlands that are concentrated in certain regions, as well as to the low demand for buffalo meat and low milk yield. 
To improve buffalo breeding in Turkey, important state subsidies are granted as in other bovine animals, as well as sheep and goat breeding. In 2016, the government support for buffalo calves aged four months and older was designated as 350 TL per head and 500 TL per animal as a studbook support (RG, 2016).

The objective of the study was to determine the problems of water buffalo sector in Turkey and the areas needing improvement. To that end, a SWOT analysis was carried out through "Focus Group Interviews" with stakeholders directly or indirectly involved in buffalo breeding activities in Turkey, the problems of the sector were identified, and then, relevant recommendations were presented.

\section{Material and Methods}

We designated seven cities (Afyonkarahisar, Bitlis, Diyarbakir, Istanbul, Muş, Samsun, and Tokat) where the primary data of the research were obtained based on the number of buffalo and the scale of buffalo milk production in that city. In this regard:

According to the data of 2015, the number of buffalo in Turkey was 133,766 heads. These seven cities contain $50.67 \%$ of this number (Afyonkarahisar, 3.87\%; Bitlis, 5.68\%; Diyarbakir, 8.60\%; Istanbul, 8.61\%; Muş, 4.55\%; Samsun, 12.75\%; and Tokat, 6.61\%).

According to the data of 2015, the amount of buffalo milk production in Turkey was 63,085 tons. About $54.16 \%$ of this amount was produced in these seven cities (Afyonkarahisar, 3.76\%; Bitlis, 6.38\%; Diyarbakir, 9.75\%; Istanbul, 9.84\%; Muş, 4.51\%; Samsun, 14.14\%; and Tokat, $5.78 \%$ ).

The cities determined within the scope of the research represent half of Turkey's data in terms of the number of buffalo and the amount of buffalo milk production. At the same time, they are the main places in Turkey engaged in water buffalo breeding.

The research material consisted of the data collected at the "Focus Group Interviews" with the participation of sector actors (buffalo farmers, producer associations, agricultural engineers, food engineers, veterinaries, cooperatives, chamber of agriculture, and private sector representatives) from the cities intensely engaged in buffalo breeding.

Focus group interview is a general concept used for interviews conducted by the researcher with the participation of many people, instead of one individual, at the same time (Punch, 2005). It is also described as a series of discussions aimed at obtaining perceptions on a previously determined subject (Yıldırım and Şimşek, 2011). The focus group interview is also defined as a qualitative method designed to learn about conscious, semi-conscious, or unconscious behaviours, as well as psychological and sociocultural characteristics of the groups and about the reasons behind such behaviour (Kroll et al., 2007). Focus group interviews are conducted in a social environment where participants can hear the views of other participants and reflect on their own views accordingly (Büyüköztürk et al., 2008; Çokluk et al., 2011). Detailed and multidimensional qualitative information on the individual's own viewpoints, experiences, tendencies, thoughts, perceptions, emotions, attitudes, and habits about the subject is determined in the direction of the research purpose (Stewart and Shamdasani, 1990; Krueger, 1994).

Conducted with a small group of participants on a specific topic, focus group interviews are usually carried out with a group of six to ten people with a common history of experience (Patton, 2002). These interviews usually last for 1-2 $\mathrm{h}$ and the participants are sought to share a common history of the subject or issue. The researcher can obtain the desired information in these interviews by asking questions one by one and by letting the group members discuss the subject matter (İslamoğlu, 2009).

Water buffalo breeding is predominantly practiced in Asia and about $98 \%$ of the global water buffalo population is contained in Asia, followed by Africa, America, and Europe (Table 1). The global water buffalo population was 164,144,424 head in 2000 and this figure increased by 18.49\%, reaching 194,463,729 in 2014 (FAOSTAT, 2017). In Turkey, on the other hand, the water buffalo population decreased from 146,000 head in 2000 to 122,141 in 2014, showing a $16.37 \%$ fall in 14 years. In the same period, the Turkish share in the global water buffalo population declined from 0.08 to $0.06 \%$.

Water buffalo breeding is practiced for the production of meat, besides milk production. Major countries with high meat and milk productivity include Bulgaria, India, Iran, Malaysia, Egypt, and Pakistan. According to 2014

Table 1 - Number of buffalo in the world (head)

\begin{tabular}{lcc}
\hline Continent & Number (2014) & Share (\%) \\
\hline Asia & $188,792,665$ & 97.08 \\
Africa & $3,949,287$ & 2.04 \\
America & $1,326,495$ & 0.68 \\
European & 395,037 & 0.20 \\
Oceania & 245 & - \\
World & $194,463,729$ & 100.00 \\
\hline Source: FAOSTAT (2017). & &
\end{tabular}


statistics, the country with the highest meat yield per buffalo was Egypt with $330.7 \mathrm{~kg}$, followed by Turkey with $241.6 \mathrm{~kg}$, Bulgaria with $194.3 \mathrm{~kg}$, and Malaysia with $181.4 \mathrm{~kg}$. The world average in buffalo meat yield is $142.0 \mathrm{~kg} / \mathrm{head}$. In terms of milk yield per buffalo, Pakistan (1934.5 kg/head) ranks the first place, followed by India $(1880.7 \mathrm{~kg} / \mathrm{head})$, Egypt (1652.0 kg/head), Iran (1511.1 kg/head), Malaysia (1457.4 kg/head), and Bulgaria (1440.9 kg/head). The world average in milk yield per buffalo is $1722.7 \mathrm{~kg} / \mathrm{head}$ (Table 2).

Turkey's production of water buffalo meat is above the world average, while its milk production still remains below the global average. The average meat production per buffalo increased from $138.3 \mathrm{~kg}$ in 2000 to $142.0 \mathrm{~kg}$ in 2014 , showing a $2.67 \%$ growth. In the same period, meat yield per buffalo in Turkey increased by $40.38 \%$, from 172.1 to $241.6 \mathrm{~kg}$. The milk yield in Turkey is $998.4 \mathrm{~kg} / \mathrm{head}$, which is below the world average. Although there was an increase by $20.86 \%$ in the world average in milk yield per buffalo in

Table 2 - World buffalo productivity indicators (2014)

\begin{tabular}{lcc}
\hline Important country & Meat $(\mathrm{kg}$ per head) & Milk $(\mathrm{kg}$ per head $)$ \\
\hline Bulgaria & 194.3 & 1440.9 \\
India & 139.2 & 1880.7 \\
Iranian & 166.3 & 1511.1 \\
Malaysia & 181.4 & 1457.4 \\
Egypt & 330.7 & 1652.0 \\
Pakistan & 117.9 & 1934.5 \\
Turkey & 241.6 & 998.4 \\
World & 142.0 & 1722.7
\end{tabular}

Source: FAOSTAT (2017) the period between 2004 and 2014, this increase remained as low as $3.20 \%$ in Turkey (FAOSTAT, 2017).

In water buffalo breeding, Turkey is above the world average in meat yield ( $\mathrm{kg} / \mathrm{head})$ and although it ranks second in the world, its milk yield per animal remains below the world average, placing the country among those with the lowest productivity. This indicates that milk production and milk productivity in water buffalo breeding in Turkey has not developed at the desired level.

Water buffalo breeding in Turkey is mainly concentrated in Bitlis and Muş, in the Eastern Anatolia; Afyonkarahisar, in the Aegean region; Diyarbakir, in the Southeastern Anatolia; Kayseri and Sivas, in the Central Anatolia; Çorum, Samsun, and Tokat, in the Black Sea region; and Istanbul, in the Marmara region.

While Turkey's water buffalo population was 146,000 head in 2000 , it saw a decrease by $2.69 \%$ and dropped to 142,073 head in 2016 (Table 3). In the same period, the buffalo population shrank in some cities, such as Samsun and Tokat, whereas other cities such as Bitlis, Diyarbakır, and Istanbul saw substantial increases.

Water buffalo husbandry in Turkey is generally performed for milk production. The annual buffalo milk production was 67,330 tons in 2000 , but this figure showed a significant decrease (6.31\%) in 2016, dropping to 63,085 tons (Table 4). In Turkey, total milk production, which was $8,408,568$ tons in 2001 , increased by 2.2 times, reaching $18,489,161$ tons in 2016 . In the same period, there was no change in the amount of buffalo milk production; therefore,

Table 3 - Number of buffalo in Turkey per year (head)

\begin{tabular}{|c|c|c|c|c|c|c|c|c|c|}
\hline \multirow{2}{*}{ Year } & \multicolumn{8}{|c|}{ Province } & \multirow{2}{*}{ Total } \\
\hline & Afyon & Bitlis & Diyarbakır & İstanbul & Muş & Samsun & Tokat & Others & \\
\hline 2000 & 4,960 & 3,590 & 3,480 & 8,160 & 6,970 & 19,670 & 15,770 & 83,400 & 146,000 \\
\hline 2001 & 4,890 & 3,590 & 3,420 & 7,920 & 6,690 & 18,290 & 14,660 & 78,540 & 138,000 \\
\hline 2002 & 4,190 & 3,659 & 3,502 & 7,976 & 5,635 & 17,045 & 10,880 & 68,190 & 121,077 \\
\hline 2003 & 3,953 & 3,268 & 4,047 & 7,088 & 5,228 & 18,185 & 9,197 & 62,390 & 113,356 \\
\hline 2004 & 2,991 & 4,403 & 3,670 & 5,728 & 5,668 & 14,903 & 9,454 & 76,583 & 109,900 \\
\hline 2005 & 2,608 & 5,518 & 3,727 & 4,351 & 5,292 & 13,467 & 8,176 & 61,826 & 104,965 \\
\hline 2006 & 2,776 & 6,098 & 3,401 & 4,364 & 6,025 & 12,262 & 7,997 & 58,093 & 100,516 \\
\hline 2007 & 2,378 & 4,764 & 2,562 & 4,466 & 6,101 & 8,581 & 6,994 & 48,809 & 84,705 \\
\hline 2008 & 2,519 & 3,115 & 2,601 & 7,027 & 6,456 & 8,515 & 7,044 & 49,020 & 86,297 \\
\hline 2009 & 2,558 & 3,301 & 3,750 & 8,883 & 3,657 & 10,769 & 6,488 & 47,801 & 87,207 \\
\hline 2010 & 2,165 & 4,870 & 5,853 & 9,475 & 4,703 & 11,380 & 6,731 & 39,549 & 84,726 \\
\hline 2011 & 5,258 & 6,037 & 7,824 & 9,497 & 4,595 & 13,152 & 6,830 & 44,039 & 97,632 \\
\hline 2012 & 5,085 & 5,599 & 8,905 & 10,513 & 5,879 & 14,041 & 7,809 & 49,604 & 107,435 \\
\hline 2013 & 5,476 & 5,998 & 9,950 & 10,982 & 6,382 & 14,324 & 8,125 & 61,284 & 117,591 \\
\hline 2014 & 4,957 & 5,705 & 10,932 & 10,284 & 6,098 & 16,483 & 8,473 & 59,182 & 122,114 \\
\hline 2015 & 5,183 & 7,594 & 11,510 & 11,518 & 6,087 & 17,043 & 8,839 & 65,992 & 133,766 \\
\hline 2016 & 5,598 & 8,338 & 13,165 & 11,100 & 7,435 & 17,944 & 9,094 & 69,399 & 142,073 \\
\hline$\%(*)$ & 112.86 & 232.25 & 378.30 & 318.96 & 106.67 & 91.22 & 57.66 & - & 97.31 \\
\hline$\%(* *)$ & 3.87 & 5.68 & 8.60 & 8.61 & 4.55 & 12.75 & 6.61 & 49.33 & 100.00 \\
\hline
\end{tabular}

Source: TUIK (2017)

$(*)$ : 2016 year $(2000=100)$.

$(* *)$ : Share of Turkey in 2015 . 
it remained at the same level. In 2001, the share of buffalo milk production in total milk production of Turkey was $0.75 \%$, but this ratio decreased to $0.34 \%$ in 2016 .

In Turkey, while total water buffalo meat production saw a decline and meat productivity ( $\mathrm{kg} / \mathrm{head})$ improved, no significant change occurred in buffalo milk production and productivity. During the period between 2000 and 2016 , the buffalo slaughter rates fell by $93.63 \%$ and meat production declined by $91.33 \%$, while meat productivity per buffalo saw a strong growth that accounted for a $36.07 \%$ increase (Table 5).

In Turkey, the total meat production was 435,778 tons in 2001 and increased about 2.69 times, reaching $1,173,042$ tons in 2016. During the same period, buffalo meat production decreased from 2,295 to 351 tons, which accounted for an $84.71 \%$ fall. In 2001 , while the share of buffalo meat production in Turkey's total meat production was $0.52 \%$, this ratio decreased to $0.03 \%$ in 2016 .

Table 4 - Buffalo milk production per year in Turkey (tons)

\begin{tabular}{|c|c|c|c|c|c|c|c|c|c|}
\hline \multirow{2}{*}{ Year } & \multicolumn{8}{|c|}{ Province } & \multirow{2}{*}{ Total } \\
\hline & Afyon & Bitlis & Diyarbakır & İstanbul & Muş & Samsun & Tokat & Other & \\
\hline 2000 & 3,430 & 1,513 & 1,144 & 7,162 & 4,024 & 8,288 & 7,224 & 34,545 & 67,330 \\
\hline 2001 & 3,458 & 1,525 & 1,102 & 6,688 & 3,658 & 7,966 & 6,767 & 32,163 & 63,327 \\
\hline 2002 & 2,964 & 1,475 & 992 & 6,978 & 2,874 & 6,523 & 4,197 & 24,922 & 50,925 \\
\hline 2003 & 1,438 & 1,319 & 1,613 & 3,813 & 3,149 & 7,694 & 4,314 & 25,438 & 48,778 \\
\hline 2004 & 1,670 & 1,288 & 1,251 & 3,129 & 2,960 & 4,170 & 3,941 & 20,870 & 39,279 \\
\hline 2005 & 877 & 1,670 & 1,260 & 2,573 & 2,655 & 3,907 & 3,445 & 21,671 & 38,058 \\
\hline 2006 & 805 & 1,602 & 1,279 & 2,526 & 3,149 & 3,847 & 2,855 & 20,295 & 36,358 \\
\hline 2007 & 811 & 1,519 & 1,003 & 2,593 & 3,117 & 2,229 & 2,518 & 16,585 & 30,375 \\
\hline 2008 & 1,014 & 1,069 & 755 & 3,387 & 3,323 & 3,125 & 2,122 & 16,627 & 31,422 \\
\hline 2009 & 861 & 1,109 & 1,651 & 3,915 & 1,789 & 3,863 & 2,053 & 17,202 & 32,443 \\
\hline 2010 & 1,224 & 1,242 & 2,958 & 4,302 & 2,446 & 5,264 & 2,251 & 15,800 & 35,487 \\
\hline 2011 & 2,088 & 1,439 & 4,016 & 4,552 & 2,353 & 5,580 & 2,370 & 17,974 & 40,372 \\
\hline 2012 & 2,346 & 1,416 & 4,562 & 5,362 & 3,221 & 6,309 & 2,698 & 21,075 & 46,989 \\
\hline 2013 & 2,605 & 1,464 & 5,127 & 5,733 & 3,437 & 6,735 & 2,858 & 23,988 & 51,947 \\
\hline 2014 & 2,263 & 1,752 & 6,099 & 5,339 & 2,841 & 8,147 & 3,050 & 25,312 & 54,803 \\
\hline 2015 & 2,359 & 4,007 & 6,121 & 6,179 & 2,834 & 8,873 & 3,619 & 28,769 & 62,761 \\
\hline 2016 & 2,607 & 4,172 & 6,619 & 5,823 & 3,035 & 8,782 & 3,060 & 28,987 & 63,085 \\
\hline$\%(*)$ & 76.00 & 275.74 & 578.58 & 81.30 & 75.42 & 105.96 & 42.35 & - & 93.69 \\
\hline$\%(* *)$ & 3.76 & 6.38 & 9.75 & 9.84 & 4.51 & 14.14 & 5.78 & 45.84 & 100.00 \\
\hline
\end{tabular}

Source: TUIK (2017).

(*): 2016 year $(2000=100)$

$(* *)$ : Share of Turkey in 2015.

Table 5 - Productivity indicators with buffalo meat and milk production in Turkey

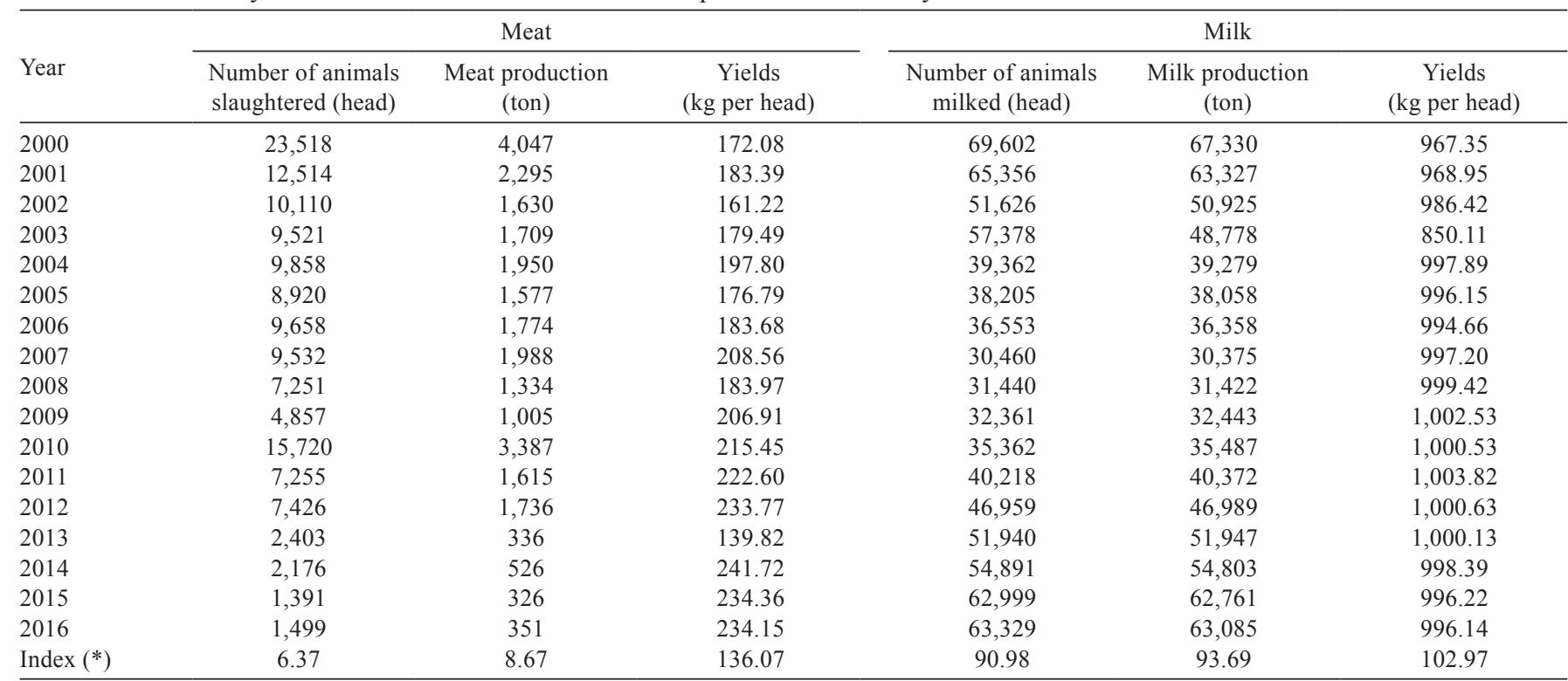

Source: TUIK (2017).

$(*)$ : 2016 year $(2000=100)$ 


\section{Results}

The SWOT analysis and interpretation of the data from focus group interviews yielded similar results obtained from the individual interviews (Table 6). After the focus group interviews, the researcher transferred the voice recordings from the interviews to the computer and completed the analysis in a text document. A common template for focus group interviews is presented below:

Regarding the focus group interview, first, the research team and the participants introduced themselves and, then, the participants were told about the scope and objectives of the research. After this phase, the focus group interview was initiated and continued within the context of the following questions:

What is the status/structure of water buffalo breeding in your region?

How do you perceive water buffalo breeding?
What are the most important problems in water buffalo farming in your region?

What should be done to improve buffalo breeding in the region?

Are there any other considerations you would like to add?

Regarding the status/structure of water buffalo breeding in Bitlis, Eastern Anatolia region, the participants reported that: breeding activities were conducted in the old barn system relying on the existing wetlands; the buffalo milk productivity was low; producers were unconscious and uneducated; and there were people who bred water buffalo just to receive some state subsidy.

Among the most important problems in water buffalo breeding in the region, there were: unconscious production, inadequate utilisation of buffalo products (meat, milk, and calf), lack of knowledge among producers, lack of feed, problems in government support, and inadequate advertising and publicity.

Table 6 - SWOT analysis of Water Buffalo

\begin{tabular}{|c|c|c|c|}
\hline Strength & Weakness & Opportunity & Threat \\
\hline $\begin{array}{l}\text { Proper utilisation of pasture } \\
\text { grounds }\end{array}$ & Need for pasture ground & $\begin{array}{l}\text { Regions engaged in water buffalo } \\
\text { breeding have suitable climate and } \\
\text { wetlands }\end{array}$ & Shrinking of wetlands \\
\hline $\begin{array}{l}\text { Resistance of animals to } \\
\text { diseases }\end{array}$ & Inadequate pasture ground & Increase in demand for buffalo milk & $\begin{array}{l}\text { Converting pasture lands into } \\
\text { agricultural areas and zoning for urban } \\
\text { settlement }\end{array}$ \\
\hline Long lifespan of animal & Small-scale enterprises & $\begin{array}{l}\text { Diversification and branding of buffalo } \\
\text { milk products }\end{array}$ & High feed and input prices \\
\hline $\begin{array}{l}\text { All types of feed can be } \\
\text { utilised }\end{array}$ & $\begin{array}{l}\text { Practicing buffalo breeding through } \\
\text { classical methods }\end{array}$ & $\begin{array}{l}\text { Advertising and promotional activities to } \\
\text { inform the public about high nutritional } \\
\text { value of water buffalo meat and milk }\end{array}$ & $\begin{array}{l}\text { Low and gradually decreasing number } \\
\text { of breeders }\end{array}$ \\
\hline High rate of feed utilisation & Low milk yield & $\begin{array}{l}\text { Encouraging and supporting young } \\
\text { farmers }\end{array}$ & $\begin{array}{l}\text { Lack of interest of the younger } \\
\text { generation in water buffalo farming }\end{array}$ \\
\hline $\begin{array}{l}\text { High nutritional value of } \\
\text { buffalo milk }\end{array}$ & Difficulty with milking & $\begin{array}{l}\text { Continuation of the Anatolian Water } \\
\text { Buffalo project }\end{array}$ & Inadequate workforce \\
\hline High meat productivity & $\begin{array}{l}\text { Consumers do not prefer buffalo } \\
\text { meat and demand is inadequate }\end{array}$ & Increase in grants and subsidies & $\begin{array}{l}\text { Urbanization (airport construction, } \\
\text { Metropolitan Act) }\end{array}$ \\
\hline $\begin{array}{l}\text { High nutritional value of } \\
\text { buffalo }\end{array}$ & $\begin{array}{l}\text { Inadequate milk collection and } \\
\text { processing facilities }\end{array}$ & $\begin{array}{l}\text { Establishment of modern enterprises and } \\
\text { growth of business scale }\end{array}$ & $\begin{array}{l}\text { Lack of knowledge about buffalo } \\
\text { products among breeders }\end{array}$ \\
\hline Less labour demand & $\begin{array}{l}\text { Challenges in marketing buffalo } \\
\text { milk and meat }\end{array}$ & Establishment of buffalo breeder union & $\begin{array}{l}\text { Low number of firms to market buffalo } \\
\text { products }\end{array}$ \\
\hline $\begin{array}{l}\text { The production costs in } \\
\text { buffalo breeding are low } \\
\text { compared with other animal } \\
\text { husbandry (dairy cows, etc.) }\end{array}$ & $\begin{array}{l}\text { Inadequate technical knowledge } \\
\text { among breeders }\end{array}$ & $\begin{array}{l}\text { Improvement studies to increase milk } \\
\text { yield }\end{array}$ & High input prices \\
\hline \multirow[t]{5}{*}{$\begin{array}{l}\text { Subsidies for water buffalo } \\
\text { breeding }\end{array}$} & $\begin{array}{l}\text { Inadequacy of producer } \\
\text { organization }\end{array}$ & $\begin{array}{l}\text { Emphasis on rural development studies } \\
\text { and encouraging on-site employment }\end{array}$ & Lack of qualified staff \\
\hline & $\begin{array}{l}\text { Existing breeder associations/unions } \\
\text { are not effective and influential }\end{array}$ & Development of contracted production & $\begin{array}{l}\text { Lack of efforts towards improving } \\
\text { buffalo breeding practices }\end{array}$ \\
\hline & Lack of operating capital & & \\
\hline & Lack of data on buffalo enterprises & & \\
\hline & $\begin{array}{l}\text { Inadequacy of agricultural publishing } \\
\text { activities }\end{array}$ & & \\
\hline
\end{tabular}


For the development of water buffalo farming in the region, the participants suggested that: loan procedures should be streamlined and low-interest loans should be allocated to those actually engaged in breeding activities; the state support was important and should continue; highyielding races should be bred or imported; facilities devoted to water buffalo products like dairies and meat processing factories should be set up; and better control mechanism should be established.

In Muş, Eastern Anatolia region, the participants commonly reported that: breeding was usually carried out by small-scale enterprises; it was based on wetland breeding system; there were no young producers; farmers preferred not to breed water buffalo as it is wilder than other bovine animals (difficulty in milking); and enterprises usually had two or three buffalo only.

The most significant problems of buffalo breeding in the region were: water shortages, difficulties in marketing buffalo products, inability to utilise young calves, and lack of young producers.

For the development of water buffalo farming in the region, the participants stated that the current state could be improved by: increasing milk yield, protection of wetlands, setting up processing facilities, raising awareness among producers, increasing and streamlining state subsidies, increasing the scale of the farms, and allocating sales spots in district markets for buffalo producers.

In Afyonkarahisar, Aegean region, the participants commonly reported that: breeding was usually carried out by small-scale family enterprises; buffalo breeding was becoming widespread day by day due to support and loan opportunities; establishment of a water buffalo producer association had a positive impact; cream from water buffalo milk was utilised in the region; and they made sausage from buffalo meat.

As for the most crucial problems in water buffalo breeding in the region, the participants reported that: breeding activities in Afyonkarahisar would be endangered due to the Metropolitan Act; wetlands had been destroyed; products obtained from buffalo were undervalued; there were no modern breeding systems; and urbanization was picking up pace.

For the development of buffalo farming in the region, the group members suggested that: buffalo breeding needed to spread to rural areas rather than to central villages; the types of subsidies had to be increased; areas such as meadows and wetlands should be protected; measures should be taken to minimize the adverse effects of the Metropolitan Act; large-scale buffalo slaughtering facilities must be established; membership to the union should be promoted; the relevant union should be authorized to implement any type of project on behalf of the farmer; new brands should be created and promoted; the Water Buffalo Breeding Project should continue; the number of brood animals should be increased; government support should be provided for farmers to facilitate the transition to modern breeding systems; and state subsidy should be granted for small businesses to set up milking units and cold-air tanks.

Regarding the state/structure of water buffalo breeding in Diyarbakır, Southeast Anatolia region, the participants reported that breeding enterprises were small-scale businesses with buffalo breeding remaining as secondary importance. They stated that buffalo breeding tended to increase in the region, which was primarily driven by the Anatolian Water Buffalo project and state subsidies.

Among the most prominent issues associated with water buffalo breeding in the region are: lack of information among producers, market constrains, conversion of pasture lands into agricultural areas, quarrels between producers about pastures, and lack of interest in buffalo milk and meat.

For the improvement of buffalo breeding in the region, the participants recommended that: utilisation of buffalo products should be varied (such as ice-cream from buffalo milk); awareness should be raised among producers; investments should be made in modern production and processing facilities; the union should be more effective; breeding efforts should be continued; buffalo products should be better promoted; and state subsidies should continue and payments should be made in two instalments.

Regarding the state/structure of water buffalo breeding in the District of Terme, Samsun - Black Sea region, the participants reported that: an old system of farming was maintained in wetlands and swamps; enterprises were small family businesses; products were mostly sold in the form of individual sales; buffalo farming was given secondary importance (main products are rice and hazelnut); and breeding was primarily based on pasture farming (the animals remained in the wetlands from April until November, so the animals were not given concentrate feed and the pasture feeding was sufficient).

The most significant problems of buffalo breeding in the region were: reduction of pasture grounds, inability to recognize the gestation in female buffalo, low yield of buffalo meat (maximum carcass weight $200 \mathrm{~kg}$ ), shrinking of pasture lands, high mortality rate of calves, physical reduction in size among the buffalo breeds in the region, high input costs, and low productivity (2-3 $\mathrm{kg}$ milk per milking, 4-6 kg per day). 
For the development of buffalo farming in the region, the participants suggested that: new brands of buffalo products should be created and promoted; larger buffalo breeds should be introduced; advertising and promotion should be increased; government support should be granted to the real producers; and support should be allocated to entrepreneurs, rather than the existing farmers.

In the District of Bafra, Samsun - Black Sea region, the participants reported that: breeding activities were mainly pasture-based farming; there were only small-scale family enterprises; and breeding was predominantly carried out in old-fashioned systems.

The most important problems in buffalo farming in the region were: poisoning of animals due to paddy irrigation seeping into streams or river waters (chemicals in the irrigation of paddy fields), lack of pasture ground, lack of market, incidents related to buffalo entering paddy fields, emigration of young population to urban areas, and low milk yield (3-4 kg per day on average).

For the development of water buffalo farming in the region, participants reported that: input costs should be lowered; different approaches such as opening dairies dedicated to water buffalo products should be developed; state support was very important and is essential for the continuation of the breeding; state subsidies should be granted to real producers; proper education should be provided to the farmers; and the new Metropolitan Act should be streamlined in favour of the breeders.

In Tokat, Black Sea region, the interviewed participants reported that: water buffalo breeding was mainly practiced by small-scale family enterprises; pasture-based breeding system was common; old-fashioned barn system was used; there was an increase in the number of breeders due to the project; breeding was easy; and the production was mainly done for those favouring buffalo products.

The most important problems of buffalo farming in the region were: lack of buffalo bulls, the lack of interest of the younger population in continuing the business, shrinking wetlands, difficulty in marketing male water buffalo, lack of available shepherds quick darkening of buffalo meat, and prejudice about buffalo products (a misconception that women eating yogurt made from buffalo milk will get pregnant at older ages because the female buffalo give birth at a relatively older age than cattle).

To improve buffalo farming in the region, the participants suggested that: state subsidies should continue and increase; regional development initiatives should be launched; support cuts should be reduced; and transition to an effective publication system should be encouraged.
Regarding the status/structure of water buffalo breeding in the District of Arnavutköy, Istanbul - Marmara Region, the participants reported that: the enterprises were largescale businesses (usually containing more than 20 head of buffalo); a combination of pasture feeding and hand feeding (usually straw, silage, sunflower seeds, wheat-barley crumbs) was utilised; and it was a good business as the region was close to the markets.

The most important problems of buffalo farming in the region were: lack of labour, inability to build new facilities due to the conservation status of the area (drinking water of Istanbul is supplied from Terkos Lake), difficulties in the sale of milk (no contracts were offered), lack of adequate pasture land due to the construction of a new airport, urbanization, and inability to continue and develop animal husbandry due to the world's largest airport construction and operation.

For the development of water buffalo farming in the region, the priorities were reported to be: advertising and publicity and governmental support in social security premiums of the workers employed.

Regarding the status/structure of water buffalo breeding in the District of Çatalca, Istanbul - Marmara region, the participants reported that: the enterprises were large-scale businesses; a combination of pasture feeding and hand feeding was utilised; and water buffalo breeding became an important line of business due to the proximity of the region to the markets.

The most important problems of buffalo farming in the region were: milk market problem (inability to sell milk from the neighbourhood) and difficulty of finding labour in buffalo farming.

For the development of water buffalo farming in the region, the participants suggested that: the products should be included in the ice-cream sector; milk sales should be increased; supply and demand should be balanced; government should pay the social insurance premiums of employed workers; efforts should be made to improve artificial insemination; animal insurances should be streamlined; people should be educated for a conscious and honest business conduct; and pasture grounds should be improved.

\section{Discussion}

Buffalo breeding is mainly carried out in Asia, with about $98 \%$ of the world buffalo population contained in this continent. The countries with high buffalo meat and milk productivity include Bulgaria, India, Iran, Malaysia, 
Egypt, and Pakistan. While the number of buffalo across the globe increased by $18.49 \%$ between 2000 and 2014, Turkey saw a huge decline (16.37\%) in its buffalo population in the same period. Meat production per buffalo was above the world average in 2014. In the same year, the milk yield per head in Turkey $(998.4 \mathrm{~kg}$ ) was below the world average (1722.7 kg per head). The main reason for this low milk yield can be attributed to the low milk productivity of the buffalo breeds existing in the country and traditional methods of pasture-based aquaculture.

The research was carried out in seven cities of Turkey (Afyonkarahisar, Bitlis, Diyarbakır, Istanbul, Muş, Samsun, and Tokat), which collectively contained $50.67 \%$ of the buffalo population in Turkey in 2015. Buffalo farms were usually small-scale family enterprises that had one or two heads of buffalo (Soysal, 2014). Işık and Gül (2016) found that $64 \%$ of the farmers in the city of Mus had fewer than 11 buffalo. In Turkey, buffalo breeding was in no position to compete with cattle milk and meat production per head. For this reason, to improve the buffalo production and to increase the yield per buffalo, the Turkish government decided to subsidize buffalo farming within the scope of state subsidies allocated to the animal husbandry sector. In 2016, the buffalo breeders received $350 \mathrm{TL}$ for each young buffalo calf they had and 500 TL for each adult buffalo in support of pedigree breeding (RG, 2016).

In general, the share of feeding costs accounts for about $70 \%$ of animal production costs. Since buffalo breeding generally relies on pasture feeding, the share of feeding costs tends to be much lower than 70\%. Günlü et al. (2010) calculated the share of feeding costs in buffalo breeding as $42.84 \%$, while Çiçek et al. (2009) found an even lower rate of $27.26 \%$, and Iş1k and Gül (2016) determined it as $36.81 \%$. The low feeding costs and low labour costs in buffalo breeding can be explained by the fact that most farmers are engaged in buffalo husbandry to meet their basic daily needs such as milk and meat. Despite regional differences, the rate of market-focused production among breeders still remained rather low.

Thanks to their proximity to the market and higher demand for the buffalo milk, producers in İstanbul and Afyonkarahisar were engaged in buffalo breeding mostly for milk production, while those in other regions were keeping buffalo for meat production. In Istanbul, the demand for buffalo milk increased significantly and, in Afyonkarahisar, the use of buffalo milk creams in various foods as an additive was on a growing trend, which enabled the development of buffalo breeding in these cities. Salari et al. (2013) reported that the increase in demand for mozzarella cheese led to the development of buffalo farming and increased milk production. Therefore, promotion efforts for buffalo products should focus on informing the public about their valuable nutritional benefits. In that way, the scale of buffalo farming in Turkey could be enhanced, which would increase the amount of buffalo milk production.

The "Anatolian Water Buffalo Project", initiated in 2011 by the Ministry of Food, Agriculture and Livestock in eight pilot cities, proved successful in promoting buffalo husbandry in Turkey, so the testing ground for the project was extended to cover even more cities. The majority of buffalo breeders stated that this project was of vital importance for the future development of buffalo breeding across the country. For this reason, the project should be continued and its scope should be further expanded into new regions.

At the level of farmers, steps towards the improvement of the sector should include: increase in the number of modern farms with larger scales, raising awareness among farmers of the importance of organized activity, encouraging better record-keeping to enable more effective database and monitoring in buffalo farming.

At the national level, it is necessary to increase the state subsidies allocated to the buffalo-breeding sector with efficient monitoring and evaluation and ensure the protection and better management of wetlands and pasture lands.

To increase the demand for buffalo products, the sector actors should collaborate and deploy resources to raise awareness of the nutritional value of buffalo milk and meat among consumers.

Based on our findings, the problems and suggestions for the sector can be summarized as follows:

Enterprises are made up of small-scale units, which increases production costs.

Water buffalo breeding is practiced by using traditional methods and the number of modern enterprises is close to zero.

Wetlands are shrinking in size - they have been transformed into fields for other agricultural production activities or zoned for construction.

The young generation lacks interest in water buffalo husbandry, so the number of breeders is decreasing.

The costs of agricultural inputs (feed, etc.) are high.

Milk yield per buffalo is rather low; no efforts have been made to increase the milk yield.

Farmers have difficulties in the marketing of buffalo meat and milk.

Milk collection and processing facilities are insufficient. 
The nutritional value of buffalo milk and meat is not well known by consumers due to lack of publicity.

The enterprises suffer from insufficient operating capital.

There is an unmet demand for qualified staff.

Existing breeder associations/unions are not working efficiently and effectively and the breeders lack awareness about the need for organization.

There is no registration system and, thus, no reliable data can be collected.

The breeders lack access to research and publications, so they do not have adequate information about the practice.

The level of current state subsidies for animal husbandry is not adequate.

The suggestions for the sector involved efforts towards the improvement of breeding practices should be intensified and water buffalo breeds that are known to produce high milk yield should be raised.

Wetlands should be protected; their conversion into other agricultural areas or zoning for development should be prevented.

The incentive system should be improved for the establishment of modern enterprises and region-specific incentives should be granted.

The Anatolian Water Buffalo project should be developed and continued.

Promotion activities should focus on informing the public about the nutritional value of buffalo meat and milk, ensuring the continuity of such activities.

A database dedicated to water buffalo breeding should be created to collect and store reliable data.

A monitoring and assessment unit should be formed to ensure better practice of water buffalo breeding.

\section{Conclusions}

Water buffalo breeding is usually practiced in regions where climate is favourable and wetlands are abundant because of the high animal feed utilization capacity, low labour demand, and low production costs. While the global water buffalo population is growing rapidly, it is following a declining trend in Turkey, which makes it necessary to concentrate on the structural and efficiency-related problems that constitute a constraint on the development of buffalo breeding across the country.

In recent years, there has been a significant decrease in the number of buffalo in Turkey, the sharpest fall in the world - between 2000 and 2016, the buffalo population shrank by $2.69 \%$, meat production by $91.33 \%$, and milk production $6.31 \%$. Breeding concentrated in smallscale family enterprises prevents farmers from creating economies of scale, thus not allowing them to minimize their production costs. On the consumers' side, there is rather limited demand for buffalo products (meat and milk); therefore, producers face serious problems in marketing their products. To overcome such issues, we suggest that the sector should focus on establishment of large-scale modern enterprises, creating demand for buffalo milk, diversification and branding of buffalo milk products, advertising and promotional activities to inform the public about high nutritional value of water buffalo meat and milk with special emphasis on certain buffalo products like the Italian Mozzarella cheese, development of contracted production, and encouraging and supporting young farmers.

\section{Acknowledgments}

This study was a part of our research project. We would like to thank TUBITAK (Project number: 1130309) for the financial support to this project.

\section{References}

Büyüköztürk, Ş.; Kılıç Çakmak, E.; Akgün, Ö. E.; Karadeniz, Ş. and Demirel, F. 2008. Bilimsel araştirma yöntemleri (Scientific research methods) (in Turkish). Pegem Yayınları, Ankara.

Çiçek, H.; Günlü, A. and Tandoğan, M. 2009. Production function analysis of buffalo fattening enterprises in Afyonkarahisar region of Turkey. Journal of Animal and Veterinary Advances 8(11):2158-2163.

Çokluk, Ö.; Yılmaz, K. and Oguz, E. 2011. Nitel bir görüşme yöntemi: Odak grup görüşmesi (A qualitative interview method: Focus Group interview) (in Turkish). Kuramsal Eğitimbilim Dergisi 4(1):95-107.

FAOSTAT - Food and Agriculture Organization of the United Nations Statistics Division. 2017. Statistical data. Available at: $<\mathrm{http}$ //www.fao.org/faostat/en/\#data/QL $>$. Accessed on: Aug. 3, 2017.

Günlü, A.; Çiçek, H. and Tandoğan, M. 2010. Socio-economic analysis of dairy buffalo enterprises in Afyonkarahisar province in Turkey. Journal of Food, Agriculture \& Environment 8(3\&4):689-691.

Iș1k, M. and Gül, M. 2016. Economic and social structures of water buffalo farming in Muş province of Turkey. Revista Brasileira de Zootecnia 45(7):400-408.

İslamoğlu, H. 2009. Sosyal bilimlerde araştırma yöntemleri (Research methods in social sciences) (in Turkish). Beta Yayınları, İzmit.

Kroll, T.; Barbour, R. and Harris, J. 2007. Using focus groups in disability research. Qualitative Health Research 17(5):690-698.

Krueger, R. A. 1994. Focus groups: A practical guide for applied research. SAGE Publication, London.

Patton, M. Q. 2002. Qualitative research \& evaluation methods. 3rd ed. Sage Publications, Hershey, PA. 
Punch, K. F. 2005. Sosyal araştırmalara giriş: Nicel ve nitel yaklaşımlar (Introduction to social research: quantitative and qualitative approaches) (in Turkish). (Translated by Bayrak, D.; Arslan, H. B. and Akyüz, Z.). Siyasal Kitabevi, Ankara.

RG - Resmi Gazete. 2016. Hayvancillk desteklemeleri hakkinda uygulama esaslari tebliği (Communiqué on implementation principles on livestock supports) (in Turkish). Tebliğ No: 2015/17, Resmi Gazete, Say1: 29353, Tarih: 12 May1s 2015.

Salari, F.; Altomonte, I. and Martini, M. 2013. Buffalo milk: a case study of some parameters related to milk production. Large Animal Review 19(1):17-20.
Soysal, M. İ. 2014. Anatolian water buffalo husbandry in Turkey. In: Proceedings of the International Symposium on Animal Science 2014, Belgrade-Zemun.

Stewart, D. W. and Shamdasani, P. N. 1990. Focus groups: Theory and practice. SAGE Publication, Newbury Park, CA.

TUIK - Turkish Statistics Institute. 2017. Statistical data. Available at: $<$ http://www.tuik.gov.tr>. Accessed on: Aug. 2, 2017.

Yıldırım, A. and Şimşek, H. 2011. Sosyal bilimlerde nitel araştırma yöntemleri (8. basim) (Qualitative research methods in the social sciences) (in Turkish). Seçkin Yayıncılık, Ankara. 